\title{
HIGH PHYLOGENETIC DIVERSITY OF BACTERIA IN THE AREA OF PREHISTORIC PAINTINGS IN MAGURA CAVE, BULGARIA
}

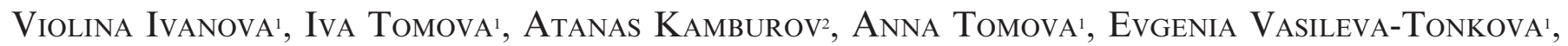 \\ and Margarita Kambourova ${ }^{*}$
}

\begin{abstract}
Magura Cave, situated in the northwest of Bulgaria and containing prehistoric paintings, is a famous tourist site. The present study is the first report on bacterial diversity in guano paintings in a Bulgarian cave using molecular methods. We identified 68 taxa, which is an unusually high number for oligotrophic niches. They are affiliated with eight phyla representing more than half of the bacterial divisions identified in caves. As in many other caves, Proteobacteria dominated in this type of ecosystem (about 40\%), followed by Nitrospirae (22.5\%) and Acidobacteria (21.5\%). Weakly represented were Actinobacteria (6.4\%), Chloroflexi (3.2\%), Planctomycetes (2.2\%), Firmicutes (2.2\%), and Gemmatimonadetes (2.2\%). About one third of all DNA sequences recovered in this study were new. Some of them had more than $10 \%$ divergence from the closest neighbor, which suggests the existence of new taxa of at least genus level. Bacteria identified in the community expressed various types of metabolism; lithoautotrophic, organotrophic, and methylotrophic.
\end{abstract}

\section{INTRODUCTION}

Karst landscapes and caves are formed in soluble rock over millions of years. In the last two centuries, traces of prehistoric life were found in many caves across the continents. The interiors of caves have stable environmental conditions such as temperature, and this has favored their occupation by prehistoric people. Several caves have authenticated paintings connected with religious and everyday habits, some of them representing real masterpieces of ancient art (Schabereiter-Gurtner et al., 2002c; Pike et al., 2012). UNESCO has recognized such caves as a valuable part of the world's cultural heritage. Caves with prehistoric images are found in France, Spain, and Italy. Until recently, the paintings found in Chauvet Cave, France were accepted as the oldest in Europe, but recent studies using radioactive decay rates of uranium revealed that the paintings in El Castillo Cave in Spain date back to at least 40,800 years, making them the oldest known cave art in Europe, five to ten thousand years older than previous examples from France (Pike et al., 2012). The cave microbiota have been well characterized in several Spanish caves, including Tito Bustillo (Schabereiter-Gurtner et al., 2002b), Altamira (Schabereiter-Gurtner et al., 2002a), and La Garma and Llonín (Schabereiter-Gurtner et al., 2004). Rock paintings are found in several Bulgarian caves, with Magura Cave being the largest and having the bestconserved images. These ancient paintings are multilayered, dating from the Neolithic and Eneolithic Ages to the beginning of the early Bronze Age (Stoytchev, 1994).

Prehistoric paintings in caves have been made predominantly with inorganic pigments including hematite (red), limonite (yellow), manganese oxide, and charcoal (black)
(Onac and Forti, 2011). There are many examples of prehistoric paintings with inorganic pigments, including black charcoal images in Chauvet Cave (Sadier et al., 2012) and ochre images in Spanish caves Tito Bustillo, Monte Castillo (Iriarte et al., 2009), Altamira (SchabereiterGurtner et al., 2002a), and El Castillo, and the French cave Niaux (Valladas et al., 1992). Two pigments were used in the Cave of Bats, Zuheros, Spain, red ones composed mainly of hematite (iron oxide) mixed with calcite and black ones of undetermined origin (Urzi et al., 2010). To the best of our knowledge, the paintings in only three caves have been created using fossilized bat guano: Magura Cave and Baylovo Cave, Bulgaria (Stoytchev, 2005), and a part of the paintings in Grotta dei Cervi, Italy (Laiz et al., 2000).

Despite its archaeological importance, the knowledge of the microbiology of caves is still incomplete. Although geomicrobiological environmental investigations have been widely published, a significant increase in biospeleological research has occurred within the last two decades (Urzì et al., 2002).

Most caves offer similar conditions for microbial growth, including a relatively constant temperature of 8 to $12{ }^{\circ} \mathrm{C}$, absence of light (preventing photosynthesis), and sparse nutrients. The relatively constant conditions ensure the stability of microbial communities, which is why karst caves can be considered as a long-term home for the same microorganisms. Without photosynthesis, caves are deprived

\footnotetext{
* Corresponding author: Institute of Microbiology, Bulgarian Academy of Sciences, 1113 Sofia, Bulgaria, margikam@microbio.bas.bg

${ }^{1}$ Institute of Microbiology, Bulgarian Academy of Sciences, Bulgaria

${ }^{2}$ Max Planck Institute for Molecular Genetics, Germany
} 
of the main energy supporting life on the earth's surface. To overcome those close-to-starvation conditions in caves, selfish competition for food is replaced by cooperative and mutualistic association (Barton and Jurado, 2007). According to Canaveras et al. (2001), caves are usually oligotrophic environments where primary production depends on autotrophic bacteria, and well-established autotrophic communities can support the growth of several chemoorganotrophic microbes (Urzi et al., 2010). Although many authors accept that autochtonic organic carbon is often produced from chemolitotrophic primary productivity in such ecosystems (Sarbu et al., 1996; Schabereiter-Gurtner et al., 2003, 2004; Opsahl and Chanton, 2006; Chen et al., 2009), others point out that wind, flowing and dripping water, or guano can provide organic material (Culver and Pipan, 2009).

According to Lehman (2007), microbial communities associated with different karst zones are distinct from each other, as supported by, for example, a domination of Firmicutes in Zuheros Cave, Spain (Urzì et al., 2010) or Streptomyces in Grotta dei Cervi, Italy (Laiz et al., 2000). On the other hand, some types of microbes are reported to be widespread in caves. Comparing five caves, Pronk et al. (2009) concluded that Delta Proteobacteria, Acidobacteria, and Nitrospira are specific cave groups. Indeed, the presence of these bacteria in caves has been mentioned by several authors (Schabereiter-Gurtner et al., 2002a, 2004; Pašić et al., 2010). Shabarova and Pernthaler (2009) suggested that three Beta Proteobacteria groups (families Oxalobacteraceae, Methylophilaceae, and Comamonadaceae) point toward a highly specialized endemic subsurface microflora. Consideration needs to be given to the possibility of contamination from drip waters or human presence for some pathogenic or enteric bacteria like Esherichia coli, Enterococcus, and Staphylococcus (Bastian et al., 2009; Kelly et al., 2009).

Among the less well known ecological zones on earth, caves located in Eastern European countries still present an opportunity for searching for taxa that could represent novel biotechnological resources. Although Magura Cave is very popular as a tourist site, its bacterial diversity had not been investigated. This report is the first cultureindependent investigation on the bacterial structure of the microbial community from the area of the prehistoric paintings in Magura Cave.

\section{Materials And Methods}

\section{Study Site and Sample Collection}

Bacterial community samples were collected from the prehistoric paintings in the Gallery, Magura Cave,

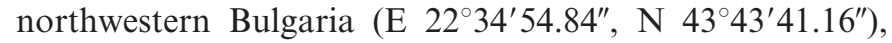
located close to the village of Rabisha. The total length of Magura Cave exceeds $2.5 \mathrm{~km}$, comprising an area of $28,600 \mathrm{~m}^{2}$. The cave offers a rich collection of geological formations of all shapes and sizes - stalactites, stalagmites,

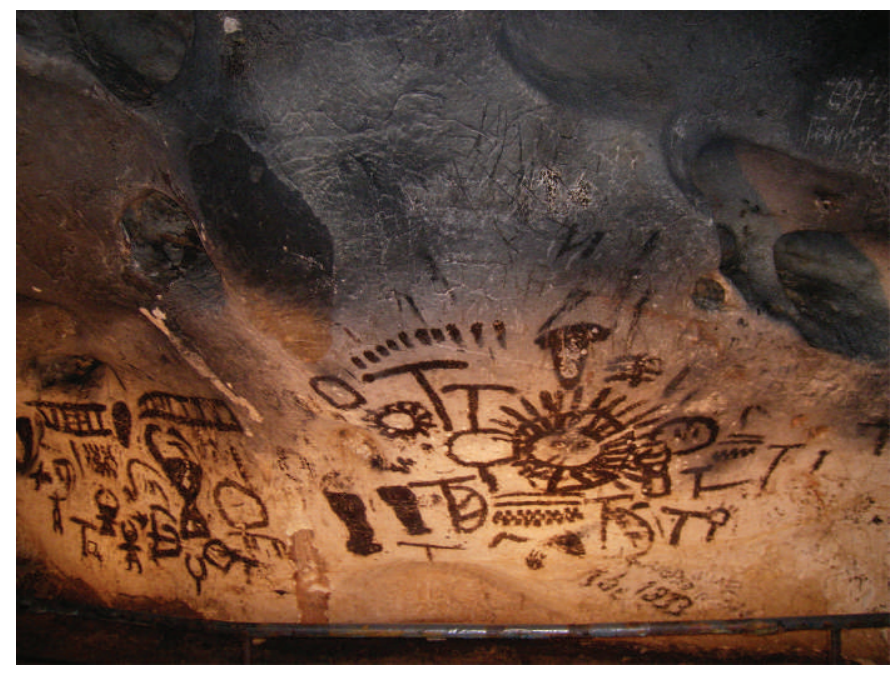

Figure 1. Some of the paintings in the Gallery, Magura Cave, including solar calendar and dancing figures.

columns, cave pearls, and flows of moonmilk. Remnants of prehistoric life, traces of settlements, and rock drawings have been found in the cave. One of the caverns, the Gallery, contains prehistoric paintings carved into the walls and decorated with bat guano. The Gallery is located on a branch off of one of the main rooms, the Landslip, and the isolated location has a constant temperature of $12{ }^{\circ} \mathrm{C}$ and a humidity of about $94 \%$. It is the highest part of the cave, is $240 \mathrm{~m}$ long and up to $24 \mathrm{~m}$ high, and has an area of $3750 \mathrm{~m}^{2}$. The drawings represent religious ceremonies, deities, and hunting scenes and include dancing male and female figures, hunting men, people wearing masks, a large variety of animals, and also suns, stars, tools, and nonfigurative, symbolic, and abstract elements. A solar calendar from the late Neolithic found there is the earliest solar calendar discovered in Europe (Fig. 1). Magura Cave was recognized as a natural landmark in May 1960 and placed on the Tentative List for consideration as a World Heritage Site by UNESCO in 1984. The cave was opened for visitors in 1961, but the Gallery was open only for five years (2002-2007).

Twelve samples were collected from the areas of different painting groups along the whole length of the Gallery wall $(105 \mathrm{~m})$ at locations separated by 5 to $11 \mathrm{~m}$. About one gram was scraped from the area of a painting or the rock within $2 \mathrm{~cm}$ of it with sterile scalpels under the supervision of the responsible archeologist from the local museum. The samples were placed in sterile tubes and transported to the laboratory in an insulated bag. All samples were mixed together and vortexted immediately after delivery to the laboratory and considered as a common sample. The procedure of total DNA isolation was initiated immediately using $10 \mathrm{~g}$ of the common sample.

The mineral composition of the rock in the area of the paintings was determined to be mainly limestone $\left(\mathrm{CaCO}_{3}\right.$, 
$74.02 \%)$, with saltpeter $\left(\mathrm{KNO}_{3}, 7.05 \%\right)$, gypsum $\left(\mathrm{CaSO}_{4}\right.$ $\left.2 \mathrm{H}_{2} \mathrm{O}, 6.25 \%\right)$, hematite $\left(\mathrm{Fe}_{2} \mathrm{O}_{3}, 5.05 \%\right)$, apatite $\left(\mathrm{Ca}_{5}\right.$ $\left.\left(\mathrm{PO}_{4}\right)_{3}(\mathrm{~F}, \mathrm{Cl}, \mathrm{OH}), 3.08 \%\right)$, calcium monohydrogen phosphate $\left.\left(\mathrm{CaHPO}_{4} \cdot 2 \mathrm{H}_{2} \mathrm{O}, 1.45 \%\right)\right]$ taranakite $\left(\mathrm{K}_{3} \mathrm{Al}_{5}\right.$ $\left.\left[\left(\mathrm{PO}_{3} \mathrm{OH}\right)_{3} \mid \mathrm{PO}_{4}\right] 2 \cdot 18 \mathrm{H}_{2} \mathrm{O}, 1.28 \%\right)$, and todorokite $\left(\mathrm{Mn}^{2+}\right.$, $\mathrm{Ca}, \mathrm{Mg}) \mathrm{Mn}_{3}{ }^{4+} \mathrm{O}_{7} \cdot \mathrm{H}_{2} \mathrm{O}, 1.25 \%$ ) (Benderev, 2006).

\section{DNA Extraction, PCR Amplification AND}

\section{CONSTRUCTION OF BaCterial 16S RRNA}

\section{Gene LiBRARY}

Total DNA was extracted from the common sample as described by Selenska-Pobell et al. (2001) with some modifications. A sample ( $10.0 \mathrm{~g}$ fresh weight) was measured aseptically and used for further analysis. The sample material was suspended in $10 \mathrm{ml}$ of $0.12 \mathrm{M}$ sodium phosphate buffer. Lysis of the cells was achieved after adding sodium dodecyl sulfate (final concentration $2 \%$ ), $\mathrm{NaCl}(0.5 \mathrm{M})$, and PEG $6000(20 \%)$. The protocol for extraction of a total-community DNA encompassed three cycles of freezing and thawing (respectively $-80{ }^{\circ} \mathrm{C}$ and 96 ${ }^{\circ} \mathrm{C}$ ), chemical lysis in an extraction buffer, and a proteinase $\mathrm{K}$ step. The crude DNA was purified with AXG-100 Nucleobond cartridges (Machery-Nagel, Duren, Germany) following the manufacturer's instructions. The eluate was precipitated by 0.7 volumes of ice-cold isopropanol. The integrity of the DNA was checked by horizontal electrophoresis in $1 \%$ agarose (Sigma) gel and visualized with ethidium bromide $(0.5 \mu \mathrm{g} / \mathrm{l})$.

Community ribosomal DNAs were amplified from 1 to $50 \mathrm{ng}$ of bulk DNA in reactions containing (as final concentrations) $1 \times$ PCR buffer, $2 \mathrm{mM} \mathrm{CaCl} 2,4 \times 200 \mu \mathrm{M}$ deoxynucleoside triphosphates, $400 \mathrm{nM}$ each forward and reverse primer, $0.5 \mathrm{U}$ Taq polymerase (GenetBio, Korea). Two universal primers for domain Bacteria were used: $8 \mathrm{~F}$ (EUB008, Hicks et al., 1992), and 1492R (EUB1492, Kane et al., 1993). Reaction mixtures were incubated in a BioRad thermal cycler (model T100) for an initial denaturation at $94{ }^{\circ} \mathrm{C}$ for $3 \mathrm{~min}$ followed by 30 cycles of $94{ }^{\circ} \mathrm{C}$ for $0.5 \mathrm{~min}$, $55^{\circ} \mathrm{C}$ for $0.5 \mathrm{~min}$, and $72{ }^{\circ} \mathrm{C}$ for $1 \mathrm{~min}$, and final extension at $72{ }^{\circ} \mathrm{C}$ for $5 \mathrm{~min}$.

For characterization of the bacterial population, a gene library was constructed of the amplified products. The PCR products were cloned in E. coli JM 109 using the pJet1.2 cloning kit (Fermentas) according to manufacturer's instructions. Cloned fragments were reamplified using the primers pJet1.2 forward and pJet1.2 reverse located in the vector and surrounding the inserted PCR fragment.

\section{Restriction Fragment Length Polymorphism (RFLP) ANALYSIS}

PCR-amplified bacterial inserts were digested using Msp I followed by digestion with Hae III (1 U each) according to the manufacturer's instructions (Fermentas). Restriction profiles were analyzed using $2 \%$ agarose gel electrophoresis. The different banding patterns were noted, and clones were grouped according to their RFLP patterns. The sequence of one clone from each group was determined.

\section{S RRNA Gene Sequencing and Analysis}

16S rRNA gene sequences were determined with an Applied Biosystems model 373A DNA sequencer by using the ABI PRISM cycle sequencing kit (Macrogen, Korea), where they were reamplified by using $8 \mathrm{~F}$ primer. Those of the clones that showed less than $97 \%$ similarity to the closest relative after sequencing with the forward primer were additionally sequenced with the reverse primer $1492 \mathrm{R}$ to establish if the full gene sequences were new $(\geq 3 \%$ evolutionary distance of the full gene).

The degree to which RFLP types covered the diversity in the sample was measured with the Shannon index (e.g., Hill et al. (2003): $\mathrm{H}=-\operatorname{sum}_{i}\left(p_{i} \ln \left(p_{i}\right)\right)$, where $p_{i}$ is the relative frequency of the $i$ th in the examined clones and $\ln$ is the natural logarithm.

The sequences obtained were checked for potential chimeric artifacts using the CHIMERA_CHECK program from RDPII on the Ribosomal Database web site (http:// rdp8.cme.msu.edu/html/analyses.html). The sequences were compared to the closest relatives in the NCBI GenBank database using BLASTn (Altschul et al., 1990) and Ribosomal Database Project resources (Maidak et al., 1994) to determine their close relatives and approximate phylogenetic affiliations. Phylogenetic analyses were conducted using $M E G A$ version 4.0 (Tamura et al., 2007) and the Neighbor-joining method (Saitou and Nei, 1987). The $16 \mathrm{~S}$ rRNA gene sequences of the sequenced clones have the Gen Bank accession numbers HE653817 to HE653888.

\section{RESUlts}

\section{Clone Library}

To determine the structure of the microbial community in the Gallery in Magura Cave, we analyzed the sequences of $16 \mathrm{~S}$ rRNA genes obtained by PCR amplification followed by cloning. The isolated 126 correct clones containing $16 \mathrm{~S}$ rRNA gene were screened by RFLP to identify unique types for sequence determination. rDNA digestion resulted in three to ten bands with the discernible fragment size range of 50 to $1000 \mathrm{bp}$ from each clone (data not shown). A total of 93 different rDNA groups were formed; 77 of them contained only one clone. More than $96 \%$ of the clone fragments sequenced with an $8 \mathrm{~F}$ primer were longer than $900 \mathrm{bp}$. Sequences for which the similarity to the closest relative was less than $97 \%$ for the full gene sequence were defined as new. They represented $31.9 \%$ of all clone sequences. Sequences differing only slightly ( $\leq$ $2 \%$ ) were considered as a single relatedness group. Clone analysis revealed the presence of eight bacterial phyla. These were Proteobacteria, Acidobacteria, Nitrospirae, Actinobacteria, Planctomycetes, Firmicutes, Chloroflexi, and Gemmatimonadetes. 


\section{PROTEOBACTERIA}

Thirty-seven of the clones in the library assigned to thirty restriction groups were related to Proteobacteria (Fig. 2), subphyla Alpha, Beta, Gamma, and Delta.

The taxonomic groups affiliated with Alpha Proteobacteria were represented by one clone for each group (nine clones, nine groups). Unlike all other groups, most of the sequences related to Alpha Proteobacteria had culturable microorganisms as closest neighbors (orders Rhizobiales and Sphingomonadales). Identified clones represented metabolic types methylotrophs (Methylobacterium and Hyphomicrobium) and heterotrophs (Sphingomonas). Aerobic metabolism was characteristic for all identified genera.

With respect to Beta Proteobacteria, nine clones were spread in six groups and corresponded to two orders, Burkholderiales (genera Methylibium and Duganella) and Rhodocyclales (family Rhodocyclaceae). More than half of the clones (five out of nine) were affiliated with the genus Methylibium, including facultative anaerobes, methylotrophs, or organotrophs with optimal growth at $\mathrm{pH} 6.5$ and temperature $30{ }^{\circ} \mathrm{C}$ (Nakatsu et al., 2006). Bacteria from the genus Duganella are strict aerobes and also organotrophs. The microorganisms from the family Rhodocyclaceae prefer oligotrophic niches and have diverse metabolisms.

Most of the Proteobacteria clones referred to the subphylum Gamma Proteobacteria (fifteen clones spread in eleven groups). Only two of these sequences grouped together with culturable microorganisms from the genera Nitrococcus and Enterobacter; all others grouped together with unculturable sequences. Microorganisms from the genus Nitrococcus oxidize nitrites to nitrates and play a key role in nitrate cycling. Two of the sequences (HE653823 and HE653851) related to family Chromatiaceae are novel. They have 92 to $95 \%$ similarity to the closest neighbor. Chromatiaceae are sulfur bacteria, oxidizing sulfides.

Four clones distributed in four different groups corresponded to Delta Proteobacteria representing anaerobic sulfate-reducing bacteria. All phylogenetic neighbors of the clones from this subphylum were unculturable bacteria. Three of the four sequences in this subphylum are new, with similarity 93 to $96 \%$ to the unculturable sulfatereducing bacteria from the order Syntrophobacterales and saprophytic order Myxococcales. The role of the Delta Proteobacteria is hypothetical due to the low phylogenetic similarity. Sequences related to Epsilon Proteobacteria were not identified in Magura Cave.

\section{NITROSPIRAE}

All identified twenty-one sequences from this phylum were referred to the genus Nitrospira; nineteen of them had environmental sequences as closest neighbors (Fig. 3). Five clones were only distantly related, with similarity 88 to $95 \%$, suggesting the existence of new taxa in the phylum. Sequence HE653833 showed 89\% similarity with the closest unculturable neighbor and $88 \%$ with the culturable
Candidatus Nitrospira defluvii. One of the sequences (HE653821) had already been identified in another cave, Pajsarjeva jama, Slovenia (Pašić et al., 2010). Although a small number of culturable Nitrospirae are known, all of them are obligate chemolithotrophs.

\section{ACIDOBACTERIA}

Twenty of the clones spread in twelve groups were referred to the phylum Acidobacteria (Fig. 4). All identified sequences grouped together with environmental sequences, unlike the Acidobacteria taxa identified in La Garma Cave, Spain, which were closer to culturable representatives of the phylum (Schabereiter-Gurtner et al., 2004). Acidobacteria is a monophyletic phylum comprising eleven deeply branched groups (Zimmerman et al., 2005). Three of them (1,3, and 7) were identified in Magura's Gallery. Half of the identified Acidobacteria sequences showed low similarity to the closest neighbors ( 92 to $95 \%$ ), suggesting that the Acidobacteria community in Magura Cave differs from those described so far.

\section{ACTINOBACTERIA}

Actinobacteria was weakly presented by six clones spread in five groups (Fig. 4). All five sequences showed highest similarity with environmental sequences; two of them corresponded to order Actinomycetales and one to the family Acidothermaceae.

\section{Phyla Planctomycetes, Firmicutes, Chloroflexi, AND GEMMATIMONADETES}

Phyla weakly represented in the community (less than $10 \%$ ) were Chloroflexi ( 3 clones, 3 groups), Planctomycetes ( 2 clones, 2 groups), Firmicutes (2 clones, 2 groups), and Gemmatimonadetes (2 clones, 1 group) (Table 1). One of the Chloroflexi sequences (HE653852) showed 92\% similarity to the closest neighbor, and one of the Planctomycetes sequences (HE653854) showed 95\% similarity.

\section{DisCUSSION}

The culture-independent approach to microbiological investigations of caves with prehistoric paintings has revealed an unusually complicated structure of bacterial communities (Gurtner et al., 2000; Schabereiter-Gurtner et al., 2002a, b; 2003; 2004) despite the commonly observed low degree of diversity for oligotrophic niches. Our phylogenetic analysis of the bacterial community in the painted Gallery in Magura Cave revealed the highest number of identified phylotypes (68) among all comparable caves. Despite the fact that the number of the analyzed clones (126) was higher than that for caves Llonín (27), La Garma (58), Altamira (21), and Tito Bustillo (41), a comparatively low diversity measure was estimated (Shannon index $\mathrm{H}=4.43$ ). This measure, which expressed the certainty of appearance of a random selected sequence, reflects the significant variety in the taxa in Magura Cave.

Journal of Cave and Karst Studies, December 2013 221 


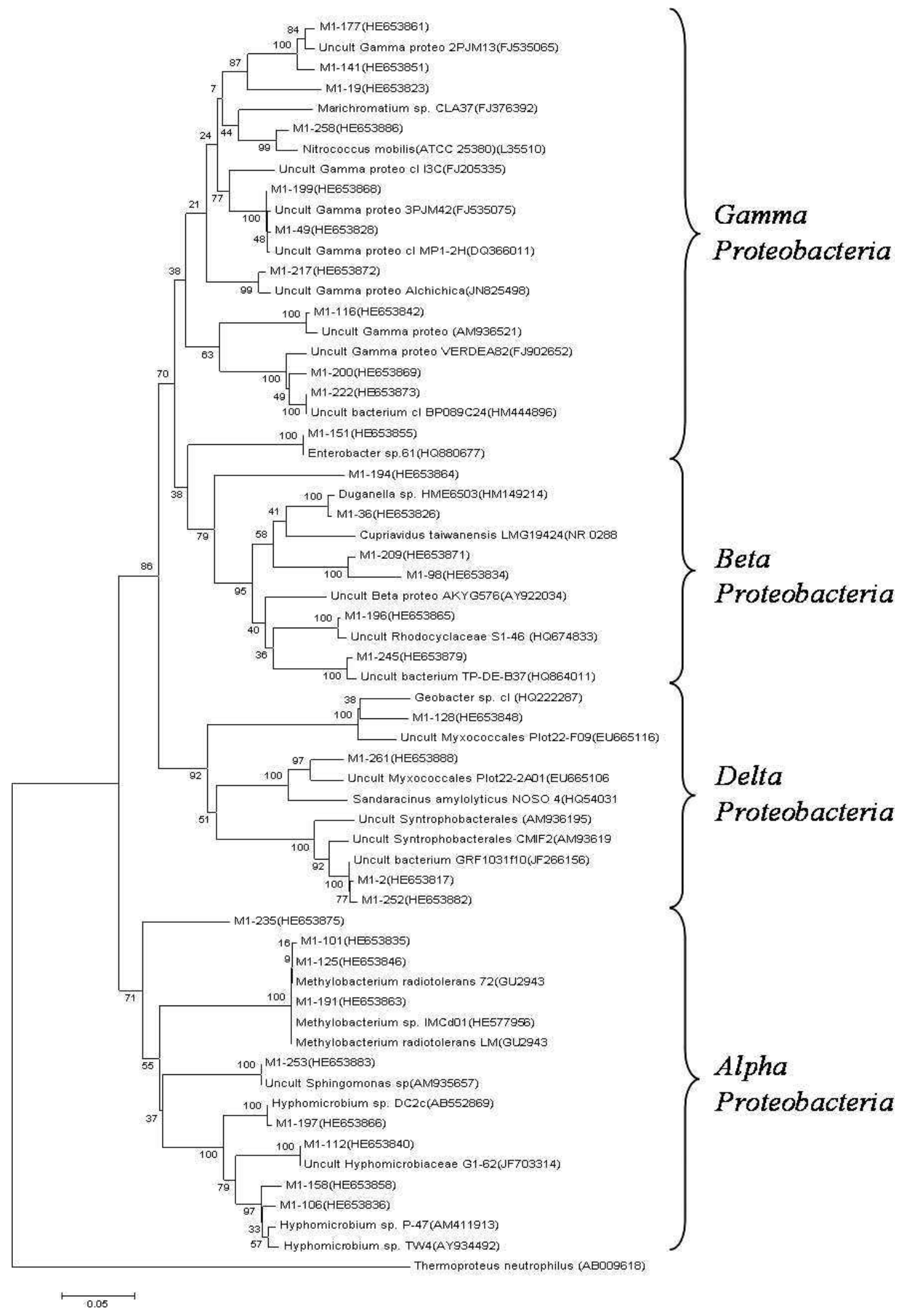

Figure 2. Neighbor-joining tree, calculated using evolutionary distances, based on the Proteobacteria 16S rRNA gene sequence types from the Magura Cave sample. Scale bar 5\% substitutions in nucleotide sequence. Bootstrap values are shown at branching points (percentage of 1000 resamplings). Sequence accession numbers are given in parenthesis. Thermoproteus neutrophilus was used as the out-group. 


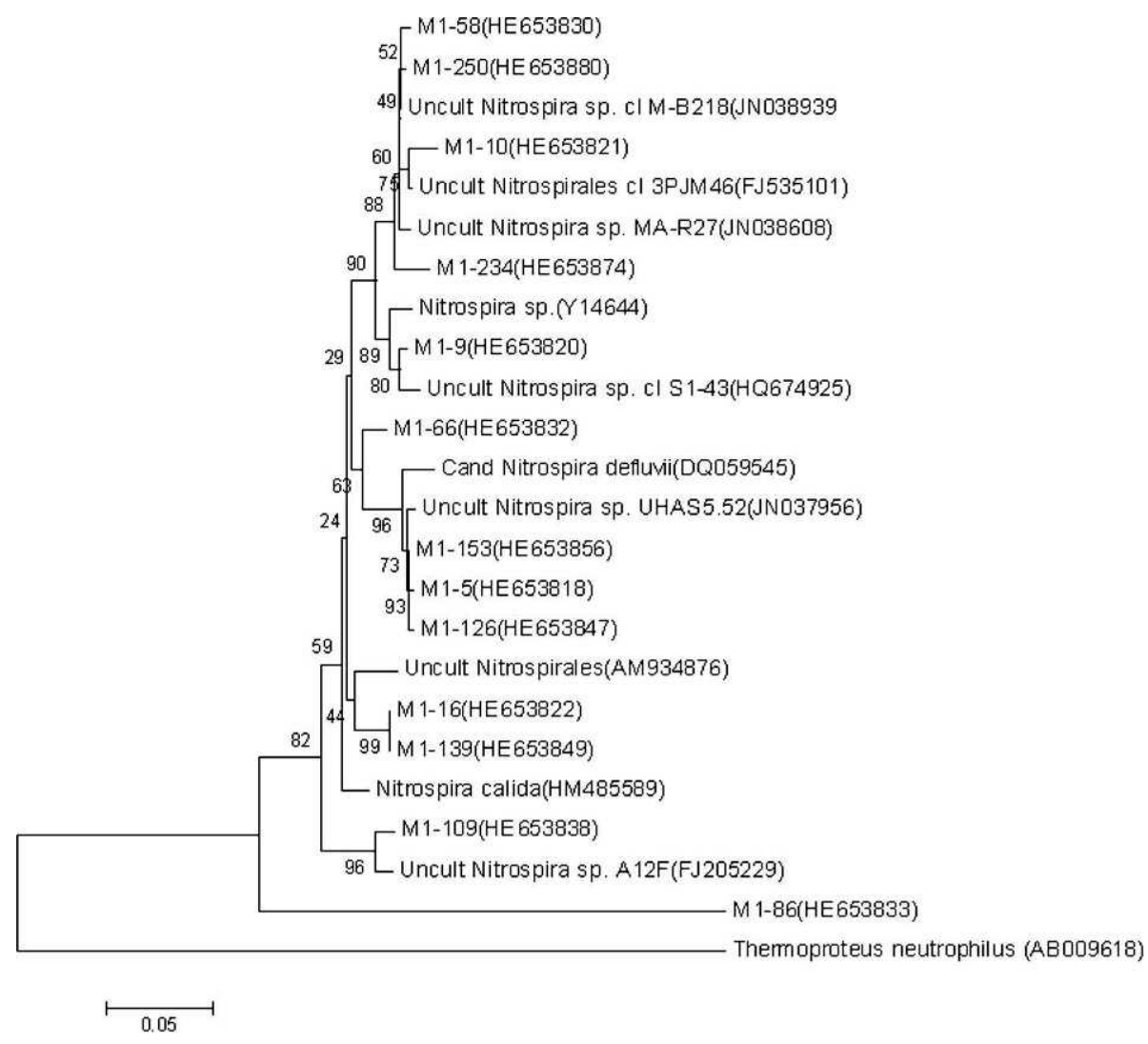

Figure 3. Neighbor-joining tree, calculated using evolutionary distances, based on Nitrospirae 16S rRNA sequence types from Magura Cave. Scale bar 5\% substitutions in nucleotide sequence. Bootstrap values are shown at branching points (percentage of 1000 resamplings). Sequence accession numbers are given in parenthesis. Thermoproteus neutrophilus was used as the outgroup.

Most of the sequences identified in Magura Cave are phylogenetically close to environmental sequences (57 out of the presented 68 phylotypes, $84 \%$ ). A predominance of unculturable phylogenetic neighbors was also observed for Altamira, Spain (62\%) (Schabereiter-Gurtner et al., 2002a), while unculturable and culturable neighbors were equally presented in the caves Llonín and La Garma, Spain (Schabereiter-Gurtner et al., 2004). Culturable neighbors of the sequences from the Magura Cave samples predominated only in the subphylum Alpha Proteobacteria and were fully absent in Delta Proteobacteria, Acidobacteria, Actinobacteria, Planctomycetes, Chloroflexi, Firmicutes, and Gemmatimonadetes. Branching of the sequences almost exclusively between unculturable bacteria confirms that a great variety of microorganisms remain undiscovered and uncharacterized in various natural microbial habitats (Ranjard et al., 2000). Our results confirm the wide spectrum of still unculturable bacteria and the importance of the culture-independent approach to understanding the whole bacterial diversity in caves.

Currently domain Bacteria comprises twenty-nine validly described taxonomic divisions (Ciccarelli et al., 2006), and according to Engel (2010) almost half of them have been identified in caves. The retrieved sequences from Magura Cave corresponded to eight bacterial phyla (Fig. 5), more than a half of the divisions reported for caves. Investigations of the samples from five caves located in different places have revealed that the number of phyla represented varied from six in Altamira Cave (Schabereiter-Gurtner et al., 2002a) and Tito Bustillo (SchabereiterGurtner et al., 2002b) to seven in Llonín and eight in La Garma (Schabereiter-Gurtner et al., 2004) and Magura Cave. A general lack of phyla unique to a given cave was observed in the phyla presented in the compared caves. Distinct phylogenetic clusters are repeatedly detected in the caves, like Proteobacteria, Nitrospirae, and Actinobacteria. Proteobacteria was found to dominate in all compared caves (Table 2). Almost $40 \%$ of the sequences retrieved in Magura samples were identified with this phylum. Phyla Nitrospirae and Acidobacteria also were presented as dominant groups (more than 10\%). Five other phyla (Actinobacteria, Planctomycetes, Firmicutes, Chloroflexi and Gemmatimonadetes) were weakly represented.

The highest similarity in the presented bacterial groups and their degrees of domination was observed between Magura Cave and La Garma, Spain (Schabereiter-Gurtner

Journal of Cave and Karst Studies, December 2013 223 


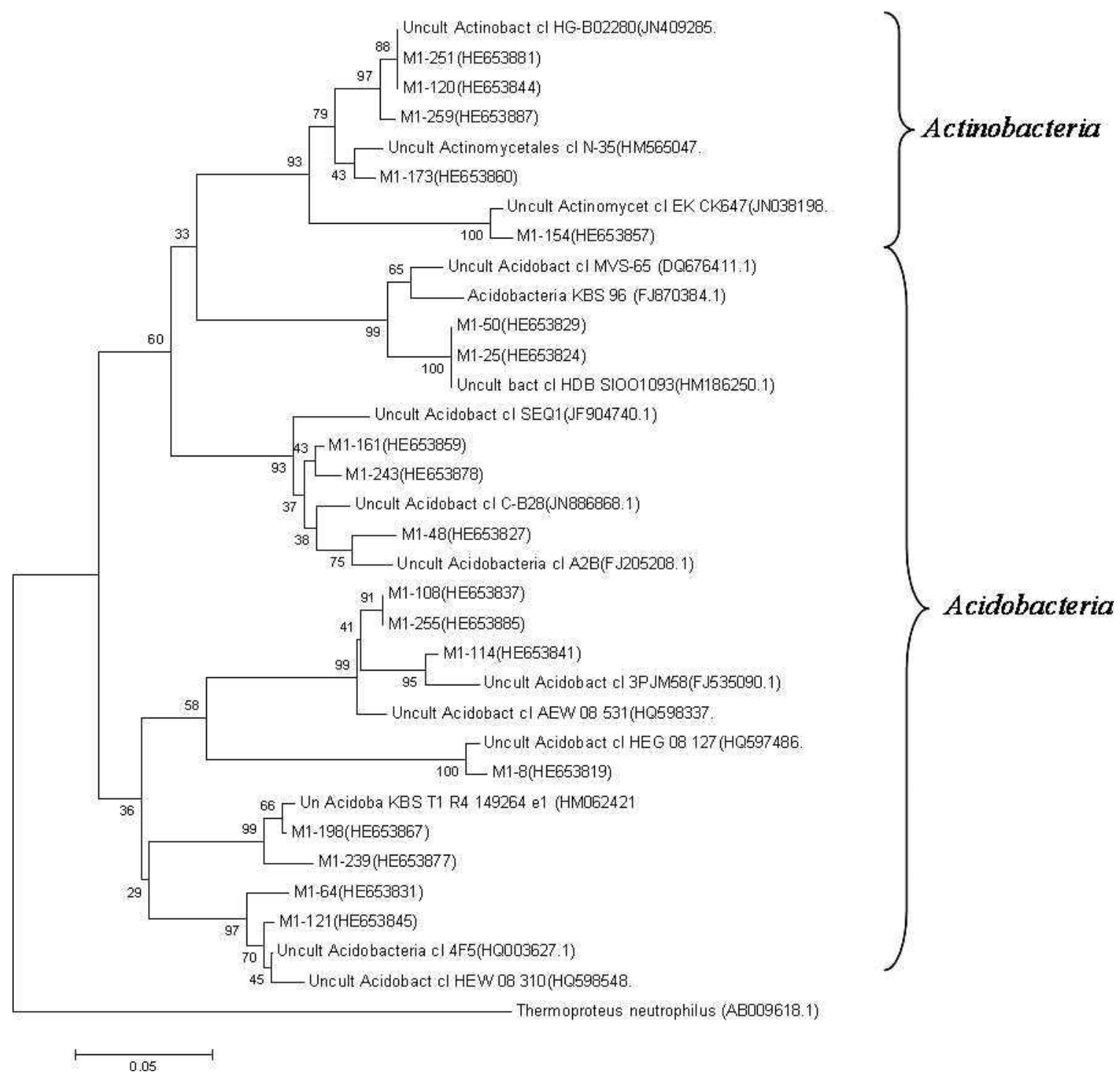

Figure 4. Neighbor-joining tree, calculated using evolutionary distances, based on Acidobacteria and Actinobacteria 16S rRNA sequence types from Magura Cave. Scale bar 5\% substitutions in nucleotide sequence. Bootstrap values are shown at branching points (percentage of 1000 resamplings). Sequence accession numbers are given in parenthesis. Thermoproteus neutrophilus was used as the out-group.

et al., 2004). However, Actinobacteria was among the dominant groups and Nitrospirae was weakly represented in La Garma.

Nitrospirae is not a phylum established in all caves. It was found to be a dominant group only in Magura Cave. It was reported as weakly represented in Llonín and La Garma (Schabereiter-Gurtner et al., 2004) and was absent in Altamira and Tito Bustillo. Although a small number of culturable Nitrospirae are known, all they are obligate chemolithotrophs, receiving energy for their growth from nitrite oxidation.

The degree of Acidobacteria domination is similar in Magura, Altamira (Schabereiter-Gurtner et al., 2002a),
Tito Bustillo (Schabereiter-Gurtner et al., 2002b), and La Garma (Schabereiter-Gurtner et al., 2004), but this phylum was absent in Llonín. Despite the small number of isolated culturable representatives of the phylum Acidobacteria, related sequences have been identified from various environments, such as soil, fresh water sediment, and sewage sludge (Tringe et al., 2005; Janssen, 2006). Initially, low $\mathrm{pH}$ was accepted as an obligate condition for their growth (Kuske et al., 1997), but 16S rRNA genes related to Acidobacteria have been isolated from neutral soils (Dunbar et al., 1999). Quaiser et al. (2003) suggested including non-acidophilic microorganisms as a separate group in the phylum. As this phylum was recently 
Table 1. Phylogenetic affinity of 16S rRNA gene sequences of bacteria identified in the Magura Cave to sequences from the phyla Planctomycetes, Firmicutes, Chloroflexi, and Gemmatimonadetes. Sequences with similarity to the closest neighbor less than $97 \%$ are noted in bold.

\begin{tabular}{|c|c|c|c|c|}
\hline Clone and sequence & Closest identified phylogenetic relatives & Phylum & $\begin{array}{l}\text { Fragment } \\
\text { length (bp) }\end{array}$ & $\begin{array}{l}\text { Clone } \\
\text { number }\end{array}$ \\
\hline M1-146 (HE653854) & Uncultured bacterium clone FOOS7B_88 - 95\% & Planctomycetes & 1476 & 1 \\
\hline M1-117 (HE653843) & Uncultured Planctomycetes bacterium - 97\% & & 972 & 1 \\
\hline M1-237 (HE653876) & $\begin{array}{l}\text { Uncultured Gemmatimonadetes bacterium } \\
\text { clone g55-99\% }\end{array}$ & Gemmatimonadetes & 1065 & 2 \\
\hline M1-26 (HE653825) & $\begin{array}{l}\text { Uncultured Gram-positive bacterium clone } \\
\text { FTL22-97\% }\end{array}$ & Firmicutes & 1420 & 1 \\
\hline M1-204 (HE653870) & Uncultured bacterium clone SWB36 - 98\% & & 1412 & 1 \\
\hline M1-144 (HE653852) & $\begin{array}{l}\text { Uncultured Chloroflexi bacterium clone } \\
\text { II10F - 92\% }\end{array}$ & Chloroflexi & 1393 & 1 \\
\hline M1-145 (HE653853) & $\begin{array}{l}\text { Uncultured Gram-positive bacterium clone } \\
\text { FTL22 - 97\% }\end{array}$ & & 1458 & 1 \\
\hline M1-181 (HE653862) & $\begin{array}{l}\text { Uncultured bacterium clone HDB_SIPP610 } \\
-99 \%\end{array}$ & & 1401 & 1 \\
\hline
\end{tabular}

discovered, their ecology and metabolism are not yet sufficiently clear.

A high degree of representation of the phylum Actinobacteria was reported for the Paleolithic Cave of Bats, Zuheros, Spain (Urzi et al., 2010). As typical heterotrophs, Actinobacteria actively participate in the carbon cycle by degradation of organic wastes. Although Groth and Saiz-Jimenez (1999) described Actinomycetes as a dominant group in caves due to low temperature and high redox potential, this group was poorly presented in the Magura Cave. Despite the fact that Streptomyces representatives are commonly accepted as obligate habitants

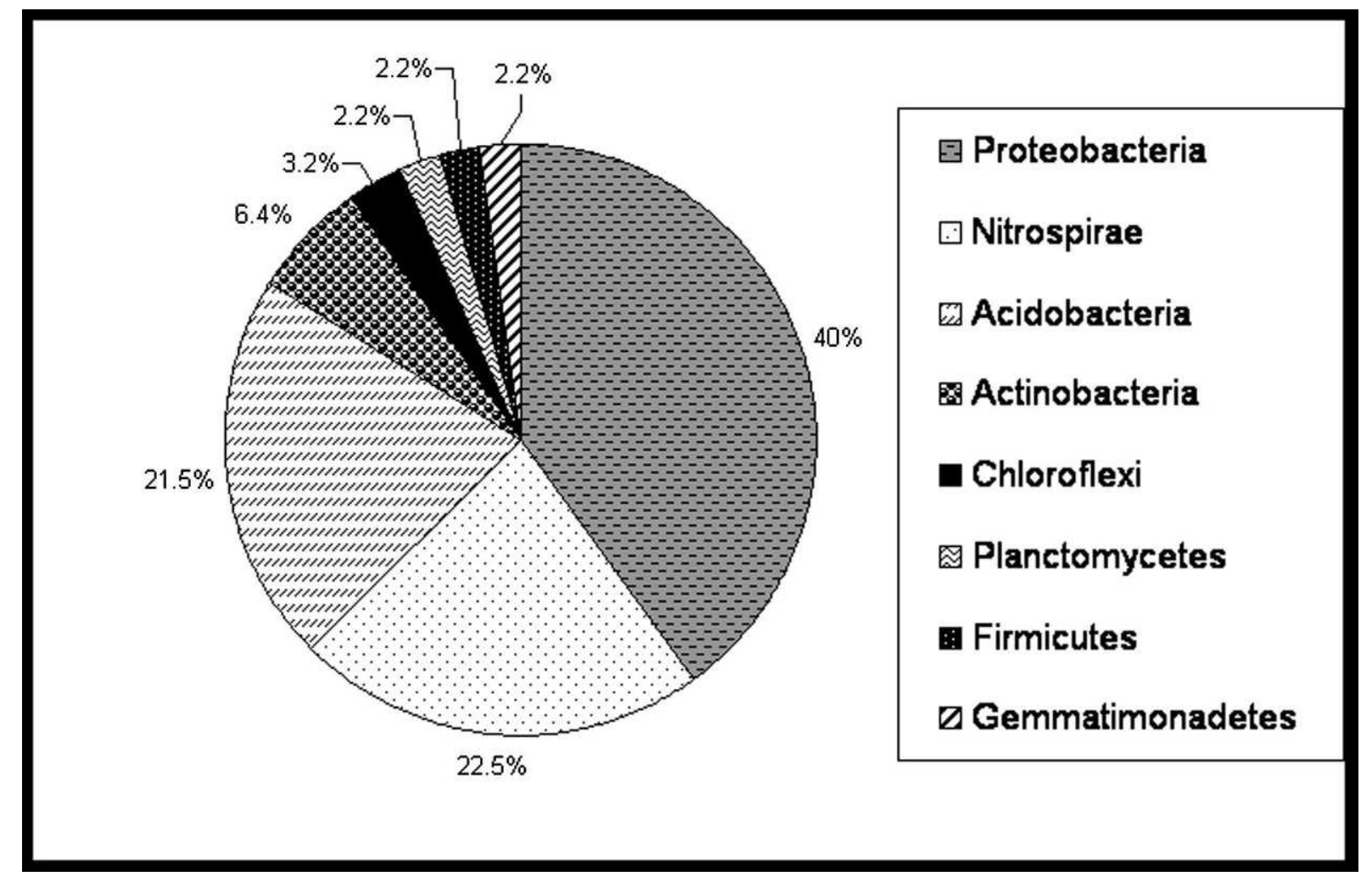

Figure 5. Comparative representation of the bacterial phyla in the sample from the area of the prehistoric paintings in Magura Cave. 
Table 2. Represented percentages of bacterial phyla in several European caves with prehistoric paintings.

\begin{tabular}{lccccc}
\hline Represented groups, \% & $\begin{array}{c}\text { Magura Cave, } \\
\text { Bulgaria }^{\mathrm{a}}\end{array}$ & La Garma, Spain $^{\mathrm{b}}$ & Llonín, Spain $^{\mathrm{b}}$ & Altamira, Spain $^{\mathrm{c}}$ & Tito Bustillo, Spain $^{\mathrm{d}}$ \\
\hline Proteobacteria & 39.8 & 32.7 & 59.2 & 52.3 & 48.8 \\
Nitrospirae & 22.5 & 3.4 & 3.7 & 0 & 0 \\
Acidobacteria & 21.5 & 24.1 & 0 & 23.8 & 29.2 \\
Actinobacteria & 6.4 & 19.0 & 22.2 & 4.8 & 9.8 \\
Planctomycetes & 2.2 & 0 & 0 & 4.8 & 0 \\
Firmicutes & 2.2 & 13.8 & 3.7 & 0 & 7.3 \\
Chloroflexi & 3.2 & 1.7 & 0 & 4.8 & 0 \\
Gemmatimonadetes & 2.2 & 0 & 0 & 0 & 2.4 \\
Cytophaga-Flexibacter- & & & & & \\
Bacteroides & 0 & 3.4 & 11.1 & & \\
\hline
\end{tabular}

\footnotetext{
a This study.

${ }^{\mathrm{b}}$ Schabereiter-Gurtner et al., 2004.

c Schabereiter-Gurtner et al., 2002a.

${ }^{\mathrm{d}}$ Schabereiter-Gurtner et al., 2002b.
}

of caves, especially near the entrance (Urzì et al., 2002), their absence in Magura Cave's Gallery could be explained by its deep position.

Magura Cave is the only one among the compared caves in which representatives of the phylum Gemmatimonadetes were identified. Isolated clones related with the phylum Gemmatimonadetes grouped with unculturable clones. Despite the fact that only one culturable representative, Gemmatimonas aurantiaca gen. nov., sp. nov has been isolated (Zhang et al., 2003), identification of sequences from this phylum from different niches suggests that it is widely distributed in nature.

Some authors suggest that the anthropogenic factor has little or no influence on bacterial communities (Laiz et al., 2000; Schabereiter-Gurtner et al., 2004). However, other authors accept identification of some bacteria, such as Bacillus, E. coli, and Staphylococcus aureus, as indicators for human presence (Lavoie and Northup, 2006). Ikner et al. (2007) suggested that Proteobacteria is slightly represented in highly visited caves (more than 200,000 visitors per year) instead of Firmicutes. However, a low frequency for the phylum Firmicutes was observed not only for Magura and Llonín; it was totally absent in Altamira and Tito Bustillo, two caves intensively visited in the past. Culturable representatives of this phylum were isolated from an area without paintings in Altamira (Canaveras et al., 2001). A low number or absence of Firmicutes sequences in cave communities suggest that this phylum does not play a key role for the functioning of cave communities. A sequence related with Enterobacter (HE653855) was isolated from Magura Cave. Identification of pathogens could be attributed not only to visitors but also to bats and insects inhabiting the caves (Jurado et al., 2010). People could also change structure of the community by their actions, for example the major changes of microbial structure in the cave Lascaux, France, where Acidobacteria, Actinobacteria, and Nitrospira were replaced by Beta and Gamma Proteobacteria after use of fungicides to prevent fungi invasion (Dupont et al., 2007).

Together with the high number of phylogenetic groups represented in Magura Cave, the current investigation revealed a presence of sequences suggestive of unknown bacterial taxa. Novelty of sequences is usually discussed in three levels of distance: $3 \%, 5 \%$ and $15 \%$, corresponding to thresholds for novelty on the levels of species, genus, and phylum respectively (Hugenholtz et al., 1998; Pašić et al., 2010). The degree of novelty of the sequences from Magura Cave deposited in GenBank was up to $12 \%$ phylogenetic distance (sequence HE653833). We didn't establish phylogenetic types having $<85 \%$ identity to the known sequences, suggesting that all sequences could be affiliated with known phyla. More than 30.9\% (21 clones) showed $<97 \%$ similarity with the sequences deposited in GenBank; similarity was less than $95 \%$ for thirteen of them, suggesting existence of novel taxa at the genus level in Magura Cave. Novel phylotypes were identified in six out of the eight phyla presented in the cave. New sequences represented half of the identified sequences in two of the phyla, Nitrospira and Acidobacteria. Two of Nitrospira sequences showed more than $10 \%$ divergence. Some of the new sequences were represented only once in the clone collection; but others like M1-48 (Acidobacteria) and M1139 (Nitrospirae) occurred in four and three clones, respectively, proving a comparatively high abundance of these new lineages in the cave.

Lack of enough nutrients in caves determines metabolic flexibility of bacterial communities. The bacterial community in Magura Cave comprises bacteria with different metabolisms, both autotrophic and heterotrophic. The Gallery is dark, and we expected lithotrophic microorganisms, 
rather than phototrophic ones, to be the primary source of organic productivity. Bacteria participating in oxidation of sulfur, sulfide, manganese, iron, nitrite, and ammonium ions have been identified in several caves (Northup et al., 2000; Vlasceanu et al., 2000; Engel et al., 2001; Holmes et al., 2001) and represent an important component of the bacterial cave community. The bacteria from phylum Nitrospirae and the genus Nitrococcus in the Gamma Proteobacteria identified in Magura Cave oxidize nitrites to nitrates. Sulfur bacteria are considered a main group participating in karst solubility and formation of secondary cave structures. Sulfur bacteria from the family Chromatiaceae were detected in Magura Cave. Other identified participants in the sulfur cycle were sulfate-reducing bacteria from the order Syntrophobacterales. The well-established chemolithotrophic part of the community provides nutrients to support chemoorganotrophic growth. Organotrophs affiliated with Alpha and Beta Proteobacteria, Planctomycetes, and Firmicutes were identified in Magura Cave. Interpretation of this information, however, should be very careful, as sometimes related organisms can express different physiologies; moreover, the same group can express different phenotypic properties in different niches (for example Actinomycetales and Actinobacteria).

Although Barton and Northup (2007) suggest that very few microbial species in caves are capable of assimilating limited but chemically complex nutrients, our phylogenetic analysis of the bacterial diversity in Magura Cave revealed that its habitants are phylogenetically diverse, with lineages referred to a number of different bacterial phyla and to different metabolic types.

\section{AcKNOWLeDGeMents}

This research work was realized with the financial support of a grant DDVU 02/73 from the Ministry of Education, Youth and Science, Bulgaria.

\section{REFERENCES}

Altschul, S.F., Gish, W., Miller, W., Myers, E.W., and Lipman, D.J., 1990, Basic local alignment search tool: Journal of Molecular Biology, v. 215 , p. 403-410. doi:10.1016/S0022-2836(05)80360-2.

Barton, H.A., and Jurado, V., 2007, What's Up Down There? Microbial Diversity in Caves: Microbe Magazine, v. 2, p. 132-138.

Barton, H.A., and Northup, D.E., 2007, Geomicrobiology in cave environments: past, current and future perspectives: Journal of Cave and Karst Studies, v. 69, p. 163-178.

Bastian, F., Alabouvette, C., Jurado, V., and Saiz-Jimenez, C., 2009, Impact of biocide treatments on the bacterial communities of the Lascaux cave: Naturwissenschaften, v. 96, p. 863-868. doi:10.1007/ s00114-009-0540-y.

Benderev, A., 2006, Hydrogeological, hydrological, hydrochemical researches in Bulgarian caves, in Beron, P., Daaliev, T., and Jalov, A., eds., Caves and Speleology in Bulgaria: Sofia, PenSoft, p. 85-93.

Cañaveras, J.C., Sanchez-Moral, S., Soler, V., and Saiz-Jimenez, C., 2001, Microorganisms and microbially induced fabrics in cave walls: Geomicrobiology Journal, v. 18, p. 223-240. doi:10.1080/01490450152467769.

Chen, Yin, Wu, Liqin, Boden, R., Hillebrand, A., Kumaresan, D., Moussard, H., Baciu, M., Lu, Yahai, and Murrell, J.C., 2009, Life without light: microbial diversity and evidence of sulfur- and ammonium-based chemolithotrophy in Movile Cave: The ISME Journal, v. 3, p. 1093-1104. doi:10.1038/ismej.2009.57.

Ciccarelli, F.D., Doerks, T., von Mering, C., Creevey, C.J., Snel, B., and Bork, P., 2006, Toward automatic reconstruction of a highly resolved tree of life: Science, v. 311, p. 1283-1287. doi:10.1126/science.1123061.

Culver, D.C., and Pipan, T., 2009, The Biology of Caves and Other Subterranean Habitats: Oxford, Oxford University Press, 254 p.

Dunbar, J., Takala, S., Barns, S.M., Davis, J.A., and Kuske, C.R., 1999, Levels of bacterial community diversity in four arid soils compared by cultivation and 16S rRNA gene cloning: Applied and Environmental Microbiology, v. 65, p. 1662-1669.

Dupont, J., Jacquet, C., Dennetière, B., Lacoste, S., Bousta, F., Orial, G., Cruaud, C., Couloux, A., and Roquebert, M.F., 2007, Invasion of the French Palaeolithic painted cave of Lascaux by members of the Fusarium solani species complex: Mycologia, v. 99, p. 526-533. doi:10.3852/mycologia.99.4.526.

Engel, A.S., Porter, M.I., Kinkle, B.K., and Kane, T.C., 2001, Ecological assessment and geological significance of microbial communities from Cesspool Cave, Virginia: Geomicrobiology Journal, v. 18, p. 259-274. doi:10.1080/01490450152467787.

Engel, A., 2010, Microbial diversity of cave ecosystems, in Loy, A., Mandl, M., and Barton, L.L., eds., Geomicrobiology: Molecular and Environmental Perspective: Dortrecht, Springer Science+Business Media, p. 219-238. doi:10.1007/978-90-481-9204-5_10.

Groth, I., and Saiz-Jimenez, C., 1999, Actinomycetes in hypogean environments: Geomicrobiology Journal, v. 16, p. 1-8. doi:10.1080/ 014904599270703.

Gurtner, C., Heyrman, J., Piñar, G., Lubitz, W., Swings, J., and Rölleke, S., 2000, Comparative analyses of the bacterial diversity on two different biodeteriorated wall paintings by DGGE and 16S rDNA sequence analysis: International Biodeterioration \& Biodegradation, v. 46, p. 229-239. doi:10.1016/S0964-8305(00)00079-2.

Hicks, R.E., Amann, R.I., and Stahl, D.A., 1992, Dual staining of natural bacterioplankton with 4',6-diamidino-2-phenylindole and fluorescent oligonucleotide probes targeting kingdom-level 16S rRNA sequences: Applied and Environmental Microbiology, v. 58, p. 2158-2163.

Hill, T.C.J., Walsh, K.A., Harris, J.A., and Moffett, B.F., 2003, Using ecological diversity measures with bacterial communities: FEMS Microbiology Ecology, v. 43, p. 1-11. doi:10.1111/j.1574-6941.2003.tb01040.x.

Holmes, A.J., Tujula, N.A., Holley, M., Contos, A., James, J.M., Rogers, P., and Gillings, M.R., 2001, Phylogenetic structure of unusual aquatic microbial formations in Nullarbor caves, Australia: Environmental Microbiology, v. 3, p. 256-264. doi:10.1046/j.1462-2920.2001.00187.x.

Hugenholtz, P., Goebel, B.M., and Pace, N.R., 1998, Impact of cultureindependent studies on the emerging phylogenetic view of bacterial diversity: Journal of Bacteriology, v. 180, p. 4765-4774.

Ikner, L.A., Toomey, R.S., Nolan, G., Neilson, J.W., Pryor, B.M., and Maier, R.M., 2007, Culturable microbial diversity and the impact of tourism in Kartchner Caverns, Arizona: Microbial Ecology, v. 53, p. 30-42. doi:10.1007/s00248-006-9135-8.

Iriarte, E., Foyo, A., Sánchez, M.A., Tomillo, C., and Setién, J., 2009, The origin and geochemical characterization of red ochres from the Tito Bustillo and Monte Castillo caves (northern Spain): Archaeometry, v. 51, p. 231-251. doi:10.1111/j.1475-4754.2008.00397.x.

Janssen, P.H., 2006, Identifying the dominant soil bacterial taxa in libraries of 16S rRNA and 16S rRNA genes: Applied and Environmental Microbiology, v. 72, p. 1719-1728. doi:10.1128/AEM.72.3.1719-1728.2006.

Jurado, V., Laiz, L., Rodriguez-Nava, V., Boiron, P., Hermosin, B., Sanchez-Moral, S., and Saiz-Jimenez, C., 2010, Pathogenic and opportunistic microorganisms in caves: International Journal of Speleology, v. 39, p. 15-24.

Kane, M.D., Poulsen, L.K., and Stahl, D.A., 1993, Monitoring the enrichment and isolation of sulfate-reducing bacteria by using oligonucleotide hybridization probes designed from environmentally derived 16S rRNA sequences: Applied and Environmental Microbiology, v. 59, p. 682-686.

Kelly, W.R., Panno, S.V., Hackley, K.C., Martinsek, A.T., Krapac, I.G., Weibel, C.P., and Storment, E.C., 2009, Bacteria contamination of groundwater in a mixed land-use karst region: Water Quality, Exposure and Health, v. 1, p. 69-78. doi:10.1007/s12403-009-0006-7.

Kuske, C.R., Barns, S.M., and Busch, J.D., 1997, Diverse uncultivated bacterial groups from soils of the arid southwestern United States that are present in many geographic regions: Applied and Environmental Microbiology, v. 63, p. 3614-3621. 
Laiz, L., Groth, I., Schumann, P., Zezza, F., Felske, A., Hermosin, B., and Saiz-Jimenez, C., 2000, Microbiology of the stalactites from Grotta dei Cervi, Porto Badisco, Italy: International Microbiology, v. 3, p. $25-30$.

Lavoie, K.H., and Northup, D.E., 2006, Bacteria as indicators of human impact in caves, in Rea, G.T., ed., 17th National Cave and Karst Management Symposium, Proceedings, p. 40-47.

Lehman, R.M., 2007, Understanding of aquifer microbiology is tightly linked to sampling approach: Geomicrobiology Journal, v. 24, p. 331-341. doi:10.1080/01490450701456941.

Maidak, B.L., Larsen, N., McCaughey, M.J., Overbeek, R., Olsen, G.J., Fogel, K., Blandy, J., and Woese, C.R., 1994, The Ribosomal Database Project: Nucleic Acids Research, v. 22, p. 3485-3487. doi:10.1093/nar/22.17.3485.

Nakatsu, C., Hristova, K., Hanada, S., Meng, Xian-Ying, Hanson, J.R., Scow, K.M., and Kamagata, Y., 2006, Methylibium petroleiphilum gen. nov., sp. nov., a novel methyl tert-butyl ether-degrading methylotroph of the Betaproteobacteria: International Journal of Systematic and Evolutionary Microbiology, v. 56, p. 983-989. doi:10.1099/ijs.0.63524-0.

Northup, D.E., Dahm, C.N., Melim, L.A., Spilde, M.N., Crossey, L.J., Lavoie, K.H., Mallory, L.M., Boston, P.J., Cunningham, K.I., and Barns, S.M., 2000, Evidence for geomicrobiological interactions in Guadalupe caves: Journal of Cave and Karst Studies, v. 62, p. 80-90.

Onac, B.P., and Forti, P., 2011, Minerogenetic mechanisms occurring in the cave environment: an overview: International Journal of Speleology, v. 40, p. 79-98.

Opsahl, S.P., and Chanton, J.P., 2006, Isotopic evidence for methanebased chemosynthesis in the Upper Floridan aquifer food web: Oecologia, v. 150, p. 89-96. doi:10.1007/s00442-006-0492-2.

Pašić, L., Kovče, B., Sket, B., and Herzog-Velikonja, B., 2010, Diversity of microbial communities colonizing the walls of a Karstic cave in Slovenia: FEMS Microbiology Ecology, v. 71, p. 50-60. doi:10.1111/ j.1574-6941.2009.00789.x.

Pike, A.W.G., Hoffmann, D.L., García-Diez, M., Pettitt, P.B., Alcolea, J., De Balbín, R., González-Sainz, C., de las Heras, C., Lasheras, J.A., Montes, R., and Zilhão, J., 2012, U-series dating of Paleolithic art in 11 caves in Spain: Science, v. 336, p. 1409-1413. doi:10.1126/ science. 1219957.

Pronk, M., Goldscheider, N., and Zopfi, J., 2009, Microbial communities in karst groundwater and their potential use for biomonitoring: Hydrogeology Journal, v. 17, p. 37-48. doi:10.1007/s10040-008-0350-x.

Quaiser, A., Ochsenreiter, T., Lanz, C., Schuster, S.C., Treusch, A.H., Eck, J., and Schleper, C., 2003, Acidobacteria form a coherent but highly diverse group within the bacterial domain: evidence from environmental genomics: Molecular Microbiology, v. 50, p. 563-575. doi:10.1046/j.1365-2958.2003.03707.x

Ranjard, L., Poly, F., and Nazaret, S., 2000, Monitoring complex bacterial communities using culture-independent molecular techniques: application to soil environment: Research in Microbiology, v. 151, p. 167-177. doi:10.1016/S0923-2508(00)00136-4.

Sadier, B., Delannoy, J.-J., Benedetti, L., Bourlès, D.L., Jaillet, S., Geneste, J.-M., Lebatard, A.-E., and Arnold, M., 2012, Further constraints on the Chauvet cave artwork elaboration: Proceedings of the National Academy of Sciences of the United States of America, v. 109 , p. $8002-8006$. doi:10.1073/pnas.1118593109.

Saitou, N., and Nei, M., 1987, The neighbor-joining method: a new method for reconstructing phylogenetic trees: Molecular Biology and Evolution, v. 4, p. 406-425.

Sarbu, S.M., Kane, T.C., and Kinkle, B.K., 1996, A chemoautotrophically based cave ecosystem: Science, v. 272, p. 1953-1955. doi:10.1126/ science.272.5270.1953.

Schabereiter-Gurtner, C., Saiz-Jimenez, C., Piñar, G., Lubitz, W., and Rölleke, S., 2002a, Altamira cave Paleolithic paintings harbor partly unknown bacterial communities: FEMS Microbiology Letters, v. 211, p. 7-11. doi:10.1111/j.1574-6968.2002.tb11195.x.

Schabereiter-Gurtner, C., Saiz-Jimenez, C., Piñar, G., Lubitz, W., and Rölleke, S., 2002b, Phylogenetic 16S rRNA analysis reveals the presence of complex and partly unknown bacterial communities in
Tito Bustillo cave, Spain, and on its Palaeolithic paintings: Environmental Microbiology, v. 4, p. 392-400. doi:10.1046/j.14622920.2002.00303.x.

Schabereiter-Gurtner, C., Saiz-Jimenez, C., Piñar, G., Lubitz, W., and Rölleke, S., 2002c, Culture-independent analyses of bacterial communities on Paleolithic paintings and surrounding rock walls in karstic caves (Altamira, Tito Bustillo, La Garma and Llonín): Coalition Newsletter, v. 5, p. 11-13.

Schabereiter-Gurtner, C., Piñar, G., Lubitz, W., Rolleke, S., and SaizJimenez, C., 2003, Acidobacteria in paleolithic painting caves, in SaizJimenez, C., ed., Molecular Biology and Cultural Heritage: Lisse, Balkema, p. 15-21.

Schabereiter-Gurtner, C., Saiz-Jimenez, C., Piñar, G., Lubitz, W., and Rölleke, S., 2004, Phylogenetic diversity of bacteria associated with Palaeolithic paintings and surrounding rock walls in two Spanish caves (Llonín and La Garma): FEMS Microbiology Ecology, v. 47, p. 235-247. doi:10.1016/S0168-6496(03)00280-0.

Selenska-Pobell, S., Kampf, G., Flemming, K., Radeva, G., and Satchanska, G., 2001, Bacterial diversity in soil samples from two uranium waste piles as determined by rep-APD, RISA and 16S rDNA retrieval: Antonie van Leeuwenhoek, v. 79, p. 149-161. doi:10.1023/ A:1010237711077.

Shabarova, T., and Pernthaler, J., 2009, Investigation of bacterioplankton communities in aquatic karst pools in Bärenschacht Cave of Bernese Oberland, in White, W.B., ed., 15th International Congress of Speleology, Proceedings: Huntsville, National Speleological Society, v.1, p. $416-421$.

Stoytchev, T., 1994, Eneolithic paintings from Magoura cave, Bulgaria: Annuary of Department of Archaeology NBU:, v. 1, p. 307-320 (In Bulgarian).

Stoytchev, T., 2005, Rock art: general classification: Agato Press, Sofia, Bulgaria, p. 24 (In Bulgarian).

Tamura, K., Dudley, J., Nei, M., and Kumar, S., 2007, MEGA4: Molecular Evolutionary Genetics Analysis (MEGA) software version 4.0: Molecular Biology and Evolution, v. 24, p. 1596-1599. doi:10. 1093/molbev/msm092.

Tringe, S.G., von Mering, C., Kobayashi, A., Salamov, A.A., Chen, K., Chang, H.W., Podar, M., Short, J.M., Mathur, E.J., Detter, J.C., Bork, P., Hugenholtz, P., and Rubin, E.M., 2005, Comparative metagenomics of microbial communities: Science, v. 308, p. 554-557. doi:10.1126/science.1107851.

Urzì, C., Donato, P., Lo Passo, C., and Albertano, P., 2002, Occurrence and biodiversity of Streptomyces strains isolated from Roman hypogea, in Galan, E., and Zezza, F., eds., Protection and Conservation of the Cultural Heritage of the Mediterranean Cities: Lisse, Balkema, p. 269-272.

Urzì, C., De Leo, F., Bruno, L., and Albertano, P., 2010, Microbial diversity in Paleolithic caves: a study case on the phototrophic biofilms of the Cave of Bats (Zuheros, Spain): Microbial Ecology, v. 60 , p. 116-129. doi:10.1007/s00248-010-9710-x.

Valladas, H., Cachier, H., Maurice, P., Bernaldo de Quirós, F., Clottes, J., Cabrera Valdés, V., Uzquiano, P., and Arnold, M., 1992, Direct radiocarbon dates for prehistoric paintings at the Altamira, El Castillo and Niaux caves: Nature, v. 357, p. 68-70. doi:10.1038/357068a0.

Vlasceanu, L., Sarbu, S.M., Engel, A.S., and Kinkle, B.K., 2000, Acidic cave-wall biofilms located in the Frasassi Gorge, Italy: Geomicrobiology Journal, v. 17, p. 125-139. doi:10.1080/01490450050023809.

Zhang, Hui, Sekiguchi, Y., Hanada, S., Hugenholtz, P., Kim, Hongik, Kamagata, Y., and Nakamura, K., 2003, Gemmatimonas aurantiaca gen. nov., sp. nov., a Gram-negative, aerobic, polyphosphateaccumulating micro-organism, the first cultured representative of the new bacterial phylum Gemmatimonadetes phyl. nov.: International Journal of Systematic and Evolutionary Microbiology, v. 53, p. 1155-1163. doi:10.1099/ijs.0.02520-0.

Zimmermann, J., Gonzalez, J.M., and Saiz-Jimenez, C., 2005, Epilithic biofilms in Saint Callixtus Catacombs (Rome) harbour a broad spectrum of Acidobacteria: Antonie van Leeuwenhoek, v. 89, p. 203-208. doi:10.1007/s10482-005-9020-3. 